this type can be induced experimentally ${ }^{8}$, and so a method for such an investigation is available.

Pennsylvania Department of Health J. E. Prier

and Department of Microbiology,

Temple University School of Medicine,

Philadelphia, Pennsylvania.

${ }^{1}$ Watanabe, F., and Azuma, M., Gann, 47, 23 (1956).

${ }^{2}$ Takayama, S., Jap. J. Genet., 33, 56 (1955).

Takayama, S., and Makino, S., Zeit. Krebsforsch., 64, 253 (1961).

- Bloom, F. G., Paff, G. H., and Noback, C. R., Amer. J. Path., 27, 119 (1951).

${ }^{5}$ Prier, J. E., Cancer Res., 23, 695 (1963).

'Prier, J. E., and Brodey, R. S., Bull. World Health Org., 29, 331 (1963). ' Pakes, S. P., Griesemer, R. A., and Kasza, L., Amer. J. Vet. Res., 26, 837

s Prier, J. E., and Johnson, J. H., J. Amer. Vet. Med. Assoc., 145, 1092 (1964).

\section{Electron Microscope Evidence for Nerves in the Mandibular Stylets of the Green Peach Aphid}

Frом his morphological investigation of the black bean aphid, Aphis fabae Scop., Weber ${ }^{1}$ concluded that the stylets do not contain nerves, and he showed the central mandibular duct to be empty. Weber's interpretation has been implicitly accepted and aphid stylets have been considered merely as needle-like, non-living, chitinous bristles.

On the basis of feeding behaviour, however, at least one earlier worker ${ }^{2}$ concluded that the stylots must have innervated chemoreceptors. Without better evidence this view had little support until Bradley ${ }^{3,4}$ found that amputation of the tip of a single mandibular stylet or insertion of the intact stylet tip into various solutions such as nitric acid, formalin, or procaine prevented feeding but greatly increased larviposition. He suggested that mandibular stylets have nerves and observed that their central duct is filled with a material which can sometimes be pulled as a thread from the cut end of the stylet. He was unable to stain or otherwise investigate it. Further work ${ }^{5}$ failed to produce electrophysiological evidence for nerves within aphid stylets, but the idea was not abandoned.

Electron microscopy was necessary, but there were many technical difficulties involved in fixation and sectioning of these small hard structures with central canals. Van Hoof ${ }^{6}$ published electron micrographs of fixed and sectioned stylets of Myzus persicae (Sulzer), but the mandibular ducts appeared empty. Several attempts have been made to investigate sections of aphid stylets at Vancouver, and from hundreds of sections we have at last obtained about thirty acceptable electron micrographs. We present here conclusive morphological evidence for nerves within the central duct of the mandibular stylets.

Heads were dissected from apterous viviparous females of $M$. persicae, fixed in Palade's fixative or in glutaraldehyde, embedded in 'Epon' or 'Araldite', and the sections were stained with uranyl acetate. Cross-sections from the proximal, middle and distal regions of mandibular stylets showed two round bodies in each central duct. Often these appeared uniformly dense, but sometimes they had a lighter core. They were surrounded by granular material. These structures resembled dendrites, but the fixation was not good enough to be sure.

When one mandibular stylet was slightly damaged during dissection, adequate penetration of the fixative was allowed and resulted in good fixation of the contents of the central duct. Sections clearly show two dendrites each with a distinct plasma membrane enclosing two neurofilaments (Fig. 1). The dendrites are surrounded by granular material, which is probably the coagulated fluid of the mandibular duct.

No sections suggest how the dendrites contact the molecules of odorous material; however, in several excellent recent electron microscope investigations ${ }^{7-11}$ of

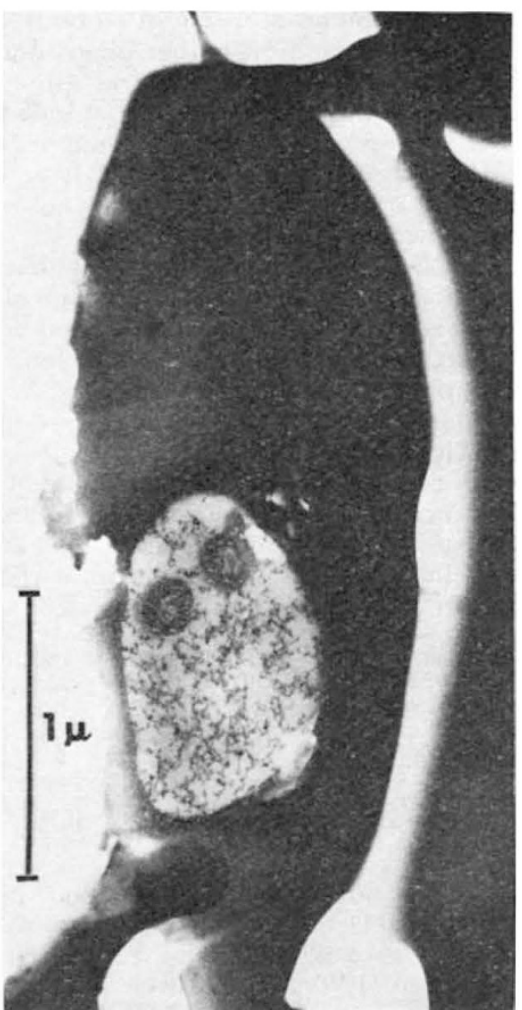

Fig. 1. Cross-section of a mandibular stylet of Myzus persicae (sulzer) showing the central duct containing two dendrites.

insect olfactory dendrites, such mediation is by way of extensions, like microvilli, of the dendrite plasma mem. brane and these enter minute pores in the wall of the sensory structure. No evidence was obtained for nerves in maxillary stylets.

The mandibular stylets of aphids have a structure consistent with that of known chemosensory hairs ${ }^{12}$. The walls of mandibular stylets are thicker than those of chemosensory hairs; this is necessary to give strength, but it does not preclude the presence of thin walled pores. The proof of innervation of the stylets is of fundamental importance to the investigation of host plant and feeding site selection by aphids.

Research Station, Research Branch.

A. R. Forbes

Canada Department of Agriculture,

6660 N.W. Marine Drive,

Vancouver 8, B.C.

${ }^{2}$ Weber, H., Zoologica, 28, 1 (1928).

2 Zweigelt, F., Zbl. Bakteriol. (Abt. 2), 42, 265 (1914).

${ }^{3}$ Bradley, R. H. E., Nature, 188, 337 (1960).

- Bradley, R. H. E., Canad, Entomol., 94, 707 (1962).

5 Anderson, J. M., and Bradley, R. H. E., Canad. J. Zool., 41, 705 (1963).

- Hoof, H. A. van, Onderzoekingen over de Biologiscne Overdracht van eeil Hoof, H. A. van, Onderzoekingen over de Biologiscne Overdracht van
Non-persistent Virus (Van Putten and Oortmeijer, Alkmaar, 1958).

'Prestage, J. J., Silfer, E. H., and Stephens, L. B., Ann. Entomol. Soc. Amer., 56, 874 (1963)

${ }^{8}$ Slifer, E. H., and Sekhon, S. S., J. Morphol., 112, 165 (1963).

9 Slifer, E. H, and Sekhon, S. S., J. Morphol., 114, 185 (1964).

${ }^{10}$ Slifer, E. H., Sekhon, S. S., and Lees, A. D., Quart. J. Micros. Sci., 105, 21 (1964).

1 Slifer, E. H., and Sekhon, S. S., J. Morphol., 114, 393 (1964).

${ }^{12}$ Dethier, V. G., Quart. Rev. Biol., 30, 348 (1955).

\section{GENETICS}

\section{Autosomal Trisomy in a Discordant Monozygotic Twin}

TURPIN et al. ${ }^{1}$ investigated a patient with Turner's syndrome who was found to have an apparently normal twin brother. Analysis of blood groups, plasma proteins and secretor status showed that they were probably 